\title{
Response of Acokanthera oblongifolia Hochst. Plants to Seaweeds Extract under Water Stress at the Early Growth Stages
}

\author{
Hoda I. M. El-Gedawey and Mona B. E. EL-Deeb \\ Agriculture Research Center, Horticulture Institute, Ministry of Agric., \\ Dept. of Ornamental \& Landscape Gardening, Antoniadis, Alex.
}

\begin{abstract}
Drought is an important abiotic stress that limits the plant growth and productivity. This experiment was done at two successive seasons of 2018/2019 and 2019/2020 to investigate the effect of seaweeds extract (algae) on the growth and quality at the early growth stages of Acokanthera oblongifolia under drought conditions. Four irrigation levels, i.e. $100 \%$ (control), $75 \%, 50 \%$ and $25 \%$ of field capacity were maintained throughout the experiment and four different concentrations of seaweeds extract (algae) [0.0 (control), 1.0, 2.0 and $3.0 \mathrm{mg} / \mathrm{l}]$ were applied as a foliar spray at 15 days intervals.

The results showed that most vegetative and root growth parameters were significantly improved by increasing the natural extract concentrations up to $2 \mathrm{mg} / \mathrm{l}$ which caused the highest significant increase in vegetative growth parameters plant height, number of leaves, and branches/plant, fresh weight, dry weight, leaf area and stem diameter). The same trend was also found for the root characters. The treatment $2 \mathrm{mg} / \mathrm{l}$ resulted in the highest significant root fresh weight, volume and dry weight. For the chemical characters (chlorophyll a, b and carbohydrate content) ,3mg/l, was the best concentration, but they were significantly decreased with decreasing water field capacity. Moreover, the percentage of proline content was reduced with increasing algae extract concentration.

According to these results, it could be concluded that 6-month-old transplants of Acokanthera oblongifolia could be irrigated under four levels of water field capacity, it has been sprayed with algae extract at $2.00 \mathrm{or} 3.00 \mathrm{mg} / \mathrm{l} \mathrm{improved}$ growth and chemical constituents under water stress.
\end{abstract}

Keywords: Acokanthera oblongifolia, seaweeds extract, water stress, chemical compouents.

\section{INTRODUCTION}

Acokanthera oblongifolia Hochst. (Synonyms Acokanthera spectabilis, Carissa oblongifolia, Toxicophloea spectabilis) common names (Bushman's poison, poison bush, poison tree, and wintersweet) belong to the family Apocynaceae that contains medium to large woody shrubs with attractive hard dark green leaves. Clusters of pinkish-white, sweetly scented flowers are borne in late winter and spring and they are followed by large plum-colored berry-like fruits which are relished by birds. The Bushman's poison is an evergreen shrub that tolerates full sun or shade and also does well as a container plant. (Arnold \& De wet ,1993 and Pooley ,1993).

Drought is an important abiotic stress that limits the plant growth and yield (Hamayun et al., 2010). One of the important factors that limits the growth, distribution of natural vegetation and the performance of cultivated plants is water deficit stress (Safaei et al., 2014). Water is an essential component of plants. It aids in absorpation and translocation of nutrients throughout the plant, serves as a medium for chemical reactions, and is necessary for photosynthesis. Plants exhibit many biochemical and physiological changes under water deficit conditions (Kidokoro et al., 2009). There is a dire need to develop strategies especially for ornamental Horticulture. Because of shortage of water worldwide, trends in gardening is changing and many water-saving techniques like use of drought -tolerant plant species. Among these introducing and developing drought-tolerant ornamental plant species is considered the most sustainable approach to cope with the drought situations. Water needs of such plant species are about $50 \%$ of the water needs of non-drought tolerant plants. Acokanthera oblongifolia is considered one of them that can grow well under these conditions. Using algae in this study was carried out to evaluate the effect of water deficit conditions on which considered as environmentally friendly material, it cause more efficient water consumption, reduction in irrigation, and providing plants with eventual moisture.

Seaweeds extract (algae) have been used as plant bio-stimulators, it can improve plant nutrient uptake and nutrient use efficiency, like growth regulators (PGRSs), and influence plant hormonal content, directly or indirectly. At low concentrations these extracts can trigger a series of physiological changes and plant responses, such as promoting growth, increasing the number of flowers, improving drought, and yield (Battacharyya et al.,2015). Seaweed extracts, also contain different phytohormones, such as indole acetic acid, cytokinin, abscisic acid, and gibberellin that could enhance plant growth (Tarakhovskaya et al., 2007). Fertilizers and PGRSs based on seaweeds are commonly known, having been produced and 
utilized for dozens of years. Algae are rich in carbohydrates, proteins, minerals and chemical compounds that belong mainly to the following groups: polysaccharides, polyphenols, plant pigments, unsaturated fatty acids, sterols and plant hormones (Gorka et al., 2018).

The aim of this study was to investigate the effects of Algae extract on vegetative growth, chemical constituents and quality of Acokanthera oblongifolia plants at the early growth stages under various drought irrigation levels.

\section{MATERIALS AND METHODS}

The studied experiments were conducted during the two seasons of 2018/2019 and 2019/2020 at Antoniades Research Branch, Horticulture Research Institute, A. R. C. Alexandria. Six months old seedling of Acokanthera oblongifolia (10-12cm) were transplanted in clay pots of $20 \mathrm{~cm}$ diameter using a mixture of sand and clay at the ratio of $1: 1$ by volume on $15^{\text {th }}$ of May in both seasons. After one month from transplanting date (on the $15^{\text {th }}$ of June of 2018 and $18^{\text {th }}$ of June2019) in the first and second seasons, respectively, irrigation treatments started. The chemical constituents of the soil were measted as described by Jackson (1958) and were illustrated in Table (1).

Two factors were studied, the first factor (four levels of water field capacity, i.e. $25 \%, 50 \%, 75 \%$ and $100 \%$ ). Water Field Capacity (WFC) measured after 24 hour from each irrigation and the second factor (algae concentrations) $0.0,1.0,2.0$ and 3.0 $\mathrm{mg} / \mathrm{l}$ were applied as a foliar spray at 15 days intervals. On The $15^{\text {th }}$ of November 2019 and $18^{\text {th }}$ of November 2020 in the first and second seasons, respectively, the experiment was terminated. The commercial product name is Algasteim, it produced by Chemia industries company. It contain different phytohormones, such as auxins, cytokinins gibberellin and some minerals that could enhance plant growth (Table 2).

Table 1: The physical and chemical properties of the used mixture soil in Antoniades park for the two seasons.

\begin{tabular}{|c|c|c|c|c|c|c|c|c|}
\hline \multirow[t]{2}{*}{ PH } & \multirow{2}{*}{$\begin{array}{c}\text { EC } \\
\text { Ds/m }\end{array}$} & \multicolumn{4}{|c|}{ Cations (meq/l) } & \multicolumn{3}{|c|}{ Anions(meq/l) } \\
\hline & & $\mathrm{Ca}++$ & $\mathrm{Mg}++$ & $\mathrm{Na}++$ & $\mathbf{K}+$ & $\mathrm{HCO}_{3}^{-}$ & $\mathrm{CL}^{-}$ & $\mathrm{SO}_{4}^{-}$ \\
\hline 8.08 & 2.53 & 18.20 & 14.20 & 23.91 & 4.49 & 7.20 & 21.00 & 27.10 \\
\hline \multicolumn{2}{|c|}{ Soil particles } & \multicolumn{2}{|c|}{ Clay } & \multicolumn{2}{|c|}{ Slit } & Sand & \multicolumn{2}{|c|}{ Soil texture } \\
\hline \multicolumn{2}{|c|}{$\%$} & \multicolumn{2}{|c|}{54.93} & \multicolumn{2}{|c|}{16.78} & 28.29 & \multicolumn{2}{|c|}{ Clay sandy loam } \\
\hline
\end{tabular}

Table 2: The analysis of the used seaweeds (Algae).

\begin{tabular}{ll}
\hline \multicolumn{1}{c}{ Component } & \\
\hline Potassium $\left(\mathrm{K}_{2} \mathrm{O}\right)$ & $10 \% \mathrm{w} / \mathrm{w}$ \\
\hline Cytokinins & $35 \mathrm{ppm}$ \\
\hline Auxins & $40 \mathrm{ppm}$ \\
\hline Gibberellins & $21 \mathrm{ppm}$ \\
\hline
\end{tabular}

The following data were measured in the two growing seasons:

Vegetative growth characters: Plant height $(\mathrm{cm})$, number of branches/plant, number of leaves /plant, fresh and dry vegetative growth weight $(\mathrm{g})$, leaf area $\left(\mathrm{cm}^{2}\right)$ and stem diameter $(\mathrm{cm})$.

Root characters: root length $(\mathrm{cm})$, root fresh and dry weights $(\mathrm{g})$, root volume $\left(\mathrm{cm}^{3}\right)$,

Chemical analysis: Chlorophyll $\mathrm{a}$ and $\mathrm{b}$ content (mg/100g fresh weight) were determined according to Moran (1982),), Anthocyanin was determined according to Mancinelli et al.,(1988), proline content(mg/100g) according to Bates et al.(1973), total carbohydrate content $(\%)$ in plant leaves according to Hedge and Hofreiter (1962) and carotene(mg/100gfresh weight) according to Wellburn(1994).

Statistical Analysis: The studied experiments were conducted as randomized complete block design (RCBD) in factorial arrangement using three replications, each replicate contained sixthteen treatments. Three plants were used as a plot for each treatment in each replicate. Data were statistically analyzed according to Gomez and Gomez (1984). Least significant difference method at 0.05 level of probability $\left(\mathrm{LSD}_{0.05}\right)$ used to compare the difference between means of the studied treatments.

\section{RESULTS AND DISCUSSION}

\section{Vegetative growth characters}

Results showed that drought levels had highly significant effects on most of the vegetative growth characters, such as plant height, number of leaves/plant, number of branches, leaf area and branches fresh weight. Among drought stress treatments (Table3). Maximum plant heights i.e, $36.84 \mathrm{~cm}$ and $42.16 \mathrm{~cm}$ were observed in the two seasons, respectively when plants grown under control condition (100\% F.C), while these were minimum $(30.25 \mathrm{~cm}, 35.72 \mathrm{~cm})$ at $25 \%$ F.C. 
It is clear that there were positive results when using foliar spray with algae extract with drought stress since $25 \% \mathrm{FC}+$ zero algae gave $25.70 \& 31.83 \mathrm{~cm}$ plant height in two successive seasons, but under $25 \% \mathrm{FC}+2.0 . \mathrm{mg} / \mathrm{l}$ gave taller plants $(33.98 \& 37.50 \mathrm{~cm})$ than $25 \% \mathrm{FC}$ only under drought stress, these results tell us we can save the $75 \%$ of irrigation water FC and get improving the growth of a plant in this case. Interaction between the irrigation, $75 \% \mathrm{FC}$ and $2 \mathrm{mg} / \mathrm{l}$ algae extract gave the tallest plant height $(44.33 \mathrm{~cm})$ in the second season compared to all treatments and it gave a similar trend in the first season $(36.11 \mathrm{~cm})$. In this study, also better response was achieved by using algae extract at $2 \mathrm{mg} / \mathrm{l}$, under drought stress conditions, which showed relatively decreases declines in plant height (Table3) with the increase in drought stress as compared to another treatments which failed to maintain the decent plant height. These results obtained that,when the data were expressed as a growth parameters compared with control of the plants, algae exerted a hormetic effect refute the idea that shaped relationship can be produced by hormones in plants (i.e., stimulation of plant growth at low-doses and growth suppression at high-doses (Poschenrieder et al. 2013; Shahid et al. 2020).

Albrecht et al. (2011\&2012) reported that growth regulators containing cytokinin, gibberellin and auxin stimulate soybean growth and observed a positive effect up to a certain dose.

Significant interaction among different water stress treatments and algae concentrations has been discussed by many scientists such as (Dhanda et al., 2004; Asghari et al., 2009; Ali et al., 2014).

It was also observed that drought stress decreased number of branches in both seasons from $75 \%$ F.C (3.16 and 3.05, respectively) to $25 \%$ F.C. (2.71\&2.54, of both seasons, respectively), and the highest number of branches realized when using algae extract at $2.0 \mathrm{mg} / \mathrm{l}$, as foliar application on plants only or as combined with $75 \%$ FC where led to the highest average number of branches per plant (4.00\&3.32branchs/plant) of two studied seasons, respectively.

The results obtained by Stirk (2004) for number of branches per Ecklonia may be due to the presence of cytokinins in extract, since this plant hormone stimulates axillary bud growth (Taiz, 2017). However, Kavalco et al. (2014) analyzed a plant growth regulators such as cytokinin, gibberellin and auxin stimulate from algae foliar application during the reproductive phase and consequently increased the number of branches in soybean plants and greater yields.

It could be noticed that the highest averages number of leaves per plant (Table 3 ) were recorded using algae extract as a foliar application (37.11 and 33.16 or 33.50$)$ at $2 \mathrm{mg} / \mathrm{l}$ combined with $75 \%$ F.C. in the first season and50\%\&75\%FC in the second season. Among, more average numbers of leaves per plant (31.23\&31.04) were recorded with algae treatment at $2 \mathrm{mg} / \mathrm{l}$, on the two seasons, respectively.

Decreasing in number of leaves with increasing drought might be due to that drought inhibits growth in association with changes in cell size and division resulting in reduced leaf production and promoting senescence and abscission (Karamanos, 1980). This reduction of leaf number under drought stress (Maqsood \& Ali, 2007) could probably be one of the drought tolerance mechanisms or water conservation strategy (Jones, 1992) under the limited soil moisture available. The reduction in the number of leaves is also observed in Lenceana leucocephala under drought stress (EI-Juhany \& Aref, 2005).

This inhibition of leaf formation also decreases volume and size of new leaf tissues resulting decrease in leaf area which was reduced to $16.64 \mathrm{~cm}^{2}$ and $13.65 \mathrm{~cm}^{2}$ at $25 \%$ F.C compared to $56.72 \mathrm{~cm}^{2}$ and $56.07 \mathrm{~cm}^{2}$ at $100 \%$ F.C in both seasons, respectively (Table 4). Also, the best highest resulted were giving when using algae extract at $1 \mathrm{mg} / \mathrm{l}$, especially at $75 \& 100 \%$ FC. Generaly, using algae at $2 \mathrm{mg} / \mathrm{l}$, gave the best results when compared to all treatments especially under drought stress.

The increment in water stress caused the reduction in leaf area where leaf became spindle and remained in a stunted state (Warrag \& Hall, 1984) to avoid the excessive transpiration with low stomatal density (Parsons, 1982) until they were rewatered. This is a special mechanism in plants to tolerate the water stress. Our results similar with the Kozlowski (1982) who noticed decreasing growth of forest trees due to water stress in details.

These results indicate the role of algae in supplying the plants with vitamins, minerals, growth regulators such as cytokinin which induces cell division and differentiation promoting proteins synthesis plus its ability to delay senescence by withdrawing sugars and other solutes from older parts to new-formed ones (Salisbury and Ross, 1974). Moreover, auxin presented in algae extract stimulate vital processes, consequently, increase assimilates which positively reflect on growth and production (Handerck and Black,2002).

Generaly, data presented in Table (4) showed that, the effect of algae extract on the fresh and dry weights of plants. It is clear that the algae application at $2 \mathrm{mg} / \mathrm{l}$ was the most effective treatment in this concern which gave 37.51 and $48.20 \mathrm{~g}$ of fresh weight and 18.22 and $16.28 \mathrm{~g}$ of dry weight/plant in the two seasons, respectively. 
Table 3: Means of Plant height (cm), Number of branches and Number of leaves/plant of Acokanthera oblongifolia Hochst. as influenced by different irrigation levels (F.C.), foliar spray of different concentrations of sea-algae extract and interaction between them during the two successive seasons of 2019 and 2020.

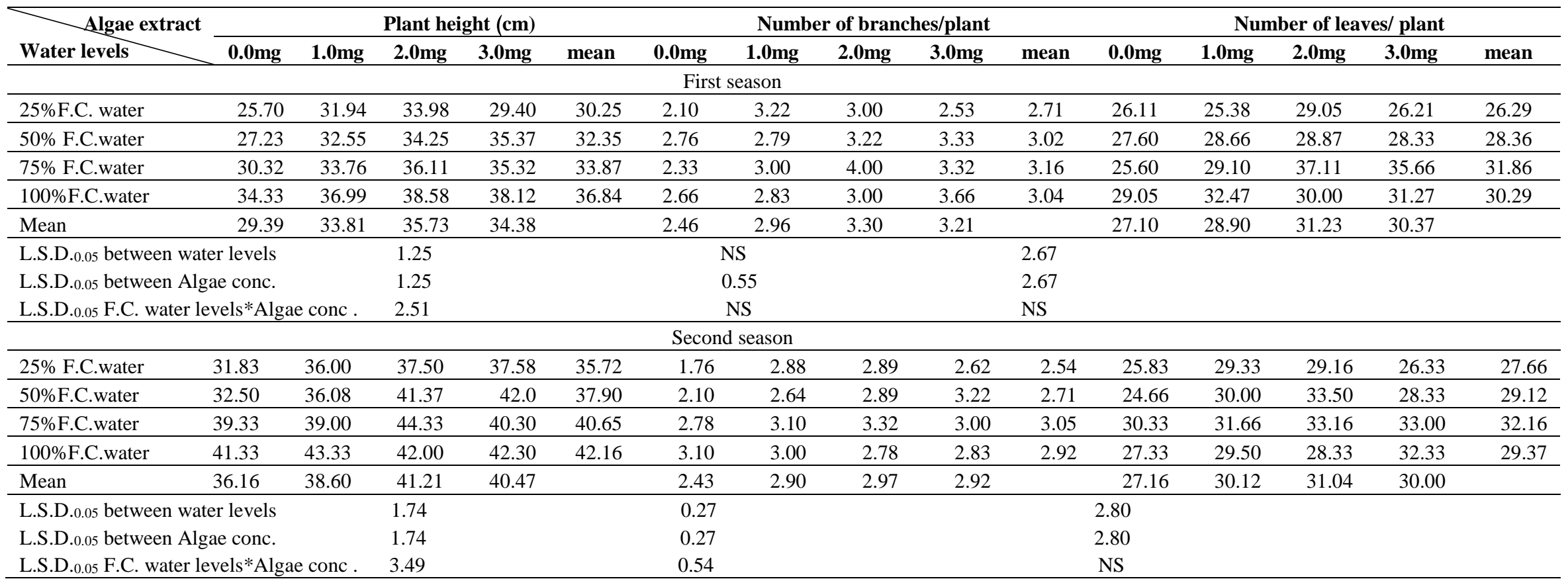


Table 4: Means of Fresh vegetative growth(g), dry vegetative growth(g) and leaf area(cm2) of Acokanthera oblongifolia Hochst. as influenced by different irrigation levels(F.C.), foliar spray of different concentrations of sea -algae extract and interaction between them during the two successive seasons of 2019 and 2020.

\begin{tabular}{|c|c|c|c|c|c|c|c|c|c|c|c|c|c|c|c|}
\hline \multirow{2}{*}{$\begin{array}{l}\text { Algae extract } \\
\text { Water levels } \\
\end{array}$} & \multicolumn{5}{|c|}{ Fresh vegetative weight $(g)$} & \multicolumn{6}{|c|}{ Dry vegetative weight(g) } & \multicolumn{4}{|c|}{ Leaf area $\left(\mathrm{cm}^{2}\right)$} \\
\hline & 0.0mg & $1.0 \mathrm{mg}$ & $2.0 \mathrm{mg}$ & $3.0 \mathrm{mg}$ & mean & $0.00 \mathrm{mg}$ & $1.00 \mathrm{mg}$ & $2.00 \mathrm{mg}$ & $3.00 \mathrm{mg}$ & mean & $0.00 \mathrm{mg}$ & $1.00 \mathrm{mg}$ & $2.00 \mathrm{mg}$ & $3.00 \mathrm{mg}$ & mean \\
\hline \multicolumn{16}{|c|}{ First season } \\
\hline $25 \%$ F.C.water & 24.28 & 26.03 & 35.95 & 30.83 & 29.27 & 10.01 & 13.77 & 19.91 & 14.56 & 14.56 & 11.63 & 18.23 & 18.00 & 18.71 & 16.64 \\
\hline 50\%F.C.water & 26.29 & 26.84 & 31.25 & 27.25 & 27.91 & 17.18 & 18.35 & 18.36 & 18.14 & 18.01 & 13.90 & 26.62 & 41.46 & 30.36 & 28.08 \\
\hline 75\%F.C.water & 30.24 & 35.16 & 42.53 & 39.18 & 36.78 & 17.56 & 16.91 & 17.78 & 18.25 & 17.63 & 20.19 & 38.62 & 60.11 & 59.80 & 44.68 \\
\hline 100\%F.C.water & 28.87 & 31.81 & 40.30 & 37.87 & 34.71 & 13.80 & 16.35 & 16.82 & 18.68 & 16.41 & 29.47 & 67.83 & 63.81 & 65.76 & 56.72 \\
\hline Mean & 27.42 & 29.96 & 37.51 & 33.78 & & 14.64 & 16.34 & 18.22 & 17.41 & & 18.80 & 37.83 & 45.84 & 43.76 & \\
\hline \multicolumn{3}{|c|}{ L.S.D.0.05 between water levels } & \multicolumn{3}{|c|}{3.35} & \multicolumn{5}{|c|}{2.15} & \multicolumn{5}{|c|}{1.83} \\
\hline \multicolumn{3}{|c|}{ L.S.D.0.05 between Algae conc. } & \multicolumn{3}{|c|}{3.35} & \multicolumn{5}{|c|}{2.15} & \multicolumn{5}{|c|}{1.83} \\
\hline \multicolumn{3}{|c|}{ L.S.D.0.05 F.C. levels*Algae conc. } & \multicolumn{3}{|c|}{$\mathrm{NS}$} & \multicolumn{5}{|c|}{ NS } & \multicolumn{5}{|c|}{3.66} \\
\hline \multicolumn{16}{|c|}{ Second season } \\
\hline 25\%F.C.water & 35.61 & 38.95 & 40.95 & 40.48 & 39.00 & 14.50 & 14.57 & 16.42 & 17.27 & 15.69 & 10.81 & 15.77 & 15.43 & 15.60 & 13.65 \\
\hline 50\%F.C.water & 41.34 & 40.67 & 47.76 & 43.68 & 43.36 & 14.70 & 17.50 & 16.24 & 15.20 & 15.91 & 12.57 & 24.97 & 30.87 & 27.85 & 24.07 \\
\hline 75\%F.C.water & 39.94 & 53.68 & 53.40 & 48.48 & 48.87 & 17.15 & 18.07 & 17.89 & 17.48 & 17.65 & 17.27 & 36.52 & 64.19 & 63.48 & 45.37 \\
\hline 100\%F.C.water & 35.21 & 55.75 & 50.70 & 49.31 & 47.74 & 16.67 & 13.99 & 14.56 & 13.96 & 14.80 & 25.53 & 66.40 & 66.04 & 66.30 & 56.07 \\
\hline Mean & 38.02 & 47.26 & 48.20 & 45.48 & & 15.75 & 16.03 & 16.28 & 15.98 & & 16.55 & 35.16 & 44.13 & 43.31 & \\
\hline \multicolumn{3}{|c|}{ L.S.D.0.05 between water levels } & \multicolumn{3}{|c|}{3.97} & \multicolumn{5}{|c|}{ NS } & \multicolumn{5}{|c|}{1.63} \\
\hline \multirow{2}{*}{\multicolumn{3}{|c|}{ L.S.D. 0.05 between Algae conc. }} & \multicolumn{3}{|c|}{3.79} & \multicolumn{5}{|c|}{ NS } & \multicolumn{5}{|c|}{1.63} \\
\hline & & & \multicolumn{2}{|r|}{ NS } & & \multicolumn{5}{|c|}{ NS } & \multicolumn{5}{|c|}{3.25} \\
\hline
\end{tabular}


As for the interaction treatments gave mostly the highest fresh and dry weights which was up to from $25 \%$ to $100 \%+2.0 \mathrm{mg} / \mathrm{l}$ in a lot of treatments. Data also indicated that increasing the rates of irrigation from $25 \%, 50 \%$ up to $100 \%$ FC resulted in significant increases in fresh and dry weights of branches in the plant.

These results are in agreement with those obtained by Ali et al., (2014) and EL-Sayed et al.,(2015). (Ramya et al.,2015) reported that the higher concentrations of the seaweed extract (above $1.5 \%$ ) were found to show retarding effect on all the growth parameters of brinjal (Solanum melongena) plants. Algal extracts impact so many parameters related to the growth and development of studied plants, suggesting that they are the right products for self-use. Application of alge extract caused a significant increase in leaf area which may be affected in gaining more sunlight to use extra $\mathrm{CO} 2$ to increase photosynthesis and accumulation of more dry matter. Stamatiadis et al. 2014 reported that when the water field capacity decreased, a higher concentration of seaweed extract was required to give positive effects as with $75 \%$ water field capacity. On plant growth, the inhibitory effect of abiotic stresses is exhibited at several levels and involves an array of cellular processes that are regulated by hormones for which homeostasis may be altered during stress (Wang et al., 2001\& Shakirova et al., 2003). However, following the application of algae extract, an increase in the number of leaves, shoots, and flowers and $\mathrm{K}: \mathrm{Na}$ ratio was found in plants subjected to compared to the untreated controls. It has been shown to contain, in relatively high amounts, phytohormones, such as abscisic acid, cytokinins, and jasmonic acid, involved in plant response to abiotic stresses (Bayona-Morcillo et al.,2020). Meyer et al., 2021. reported that biostimulant application foliar by seaweed in general, influenced the number of branches, nodes, flowers, and pods on the soybean plants and, consequently, crop yield.

Root characteristics: Data in Table (5) and (6) cleared that all treatments of algae extracts, water field capacity and their interactions caused a highly significant increase in all root characters, i.e. root volume, fresh root weigh, dry root weight and root length, expect the interaction between the two factors on root length trait in the two studied seasons.

The highest increase in root volume and root length were obtained by application of 1 or $2 \mathrm{mg} / 1$ algae extract with $50 \%$ FC $(13.59 \& 15.30 \mathrm{~cm} 3$ and $25.17 \& 25.34 \mathrm{~cm}$ ) compared to the control treatment in the first and second seasons, respectively. Also foliar spray of $2 \mathrm{mg} / \mathrm{l}+50 \%$ caused the heaviest fresh root weight $(20.23 \& 19.31 \mathrm{~g})$ and root dry weight $(10.88 \& 10.42 \mathrm{~g})$ in both seasons respectively compared to control.

Moreover, cytokinins enrichment in plant roots can cause an enhancement in the expression of genes encoding for root nitrate and sulfur transporters (Collier et al., 2003), thereby increasing plant nutrient uptake.

Table 5: Means of Stem diameter (cm), Root length (cm) of Acokanthera oblongifolia Hochst. as influenced by different irrigation levels(F.C.), foliar spray of different concentrations of sea -algae extract and interaction between them during the two successive seasons of 2019 and 2020.

\begin{tabular}{|c|c|c|c|c|c|c|c|c|c|c|}
\hline \multirow{2}{*}{$\begin{array}{l}\text { Algae extract } \\
\text { Water levels }\end{array}$} & \multicolumn{7}{|c|}{ Stem diameter $(\mathrm{cm})$} & \multicolumn{3}{|c|}{ Root length(cm) } \\
\hline & 0.00 & 1.00 & 2.00 & 3.00 & mean & 0.00 & 1.00 & 2.00 & 3.00 & mean \\
\hline \multicolumn{11}{|c|}{ First season } \\
\hline $25 \%$ F.C.water & 0.61 & 0.74 & 0.72 & 0.73 & 0.70 & 20.41 & 21.44 & 25.09 & 21.71 & 20.16 \\
\hline $50 \%$ F.C.water & 0.73 & 0.76 & 0.83 & 0.71 & 0.76 & 23.41 & 25.16 & 25.17 & 21.76 & 23.87 \\
\hline 75\% F.C.water & 0.65 & 0.77 & 0.81 & 0.81 & 0.76 & 18.49 & 18.76 & 23.47 & 20.56 & 20.32 \\
\hline $100 \%$ F.C.water & 0.69 & 0.73 & 0.73 & 0.81 & 0.74 & 17.81 & 20.32 & 20.62 & 20.20 & 19.03 \\
\hline Mean & 0.67 & 0.75 & 0.77 & 0.76 & & 20.03 & 21.42 & 23.59 & 21.06 & \\
\hline \multicolumn{3}{|c|}{ L.S.D.0.05 between water levels } & \multicolumn{3}{|c|}{ NS } & \multicolumn{5}{|c|}{1.88} \\
\hline \multicolumn{3}{|c|}{ L.S.D.0.05 between Algae conc. } & \multicolumn{3}{|c|}{0.07} & \multicolumn{5}{|c|}{1.88} \\
\hline \multicolumn{3}{|c|}{ L.S.D.0.05 F.C. levels*Algae conc. } & \multicolumn{3}{|c|}{ NS } & \multicolumn{5}{|c|}{ NS } \\
\hline \multicolumn{11}{|c|}{ Second season } \\
\hline $25 \%$ F.C.water & 0.66 & 0.76 & 0.73 & 0.76 & 0.73 & 21.70 & 22.12 & 25.16 & 22.07 & 22.76 \\
\hline 50\%F.C.water & 0.76 & 0.75 & 0.74 & 0.71 & 0.74 & 25.46 & 25.34 & 25.33 & 19.66 & 23.44 \\
\hline 75\%F.C.water & 0.64 & 0.76 & 0.82 & 0.97 & 0.79 & 18.33 & 19.74 & 25.00 & 20.03 & 20.77 \\
\hline $100 \%$ F.C.water & 0.68 & 0.78 & 0.76 & 0.71 & 0.73 & 19.03 & 20.75 & 20.76 & 20.74 & 20.32 \\
\hline Mean & 0.68 & 0.76 & 0.76 & 0.79 & & 20.63 & 21.98 & 24.06 & 20.62 & \\
\hline \multicolumn{3}{|c|}{ L.S.D.0.05 between water levels } & \multicolumn{3}{|c|}{0.04} & \multicolumn{5}{|c|}{1.82} \\
\hline \multicolumn{3}{|c|}{ L.S.D.0.05 between Algae conc. } & \multicolumn{3}{|c|}{0.04} & \multicolumn{5}{|c|}{1.82} \\
\hline \multicolumn{3}{|c|}{ L.S.D.0.05F.C. levels*Algae conc. } & \multicolumn{3}{|c|}{0.09} & \multicolumn{5}{|c|}{ NS } \\
\hline
\end{tabular}


Table 6: Means of Root fresh growth (g), Root dry growth(g) and Root volum( $\left.\mathrm{cm}^{3}\right) /$ plant of Acokanthera oblongifolia Hochst. as influenced by different irrigation levels(F.C.), foliar spray of different concentrations of sea -algae extract and interaction between them during the two successive seasons of 2019 and 2020.

\begin{tabular}{|c|c|c|c|c|c|c|c|c|c|c|c|c|c|c|c|}
\hline \multirow{2}{*}{$\begin{array}{l}\text { Algae extract } \\
\text { Water level }\end{array}$} & \multicolumn{4}{|c|}{ Root fresh weight(g) } & \multicolumn{5}{|c|}{ Root dry weight/plant } & \multicolumn{6}{|c|}{ Root volum $\left(\mathrm{cm}^{3}\right) /$ plant } \\
\hline & $0.0 \mathrm{mg}$ & $1.0 \mathrm{mg}$ & $2.0 \mathrm{mg}$ & $3.0 \mathrm{mg}$ & mean & 0.00mg & $1.00 \mathrm{mg}$ & $2.00 \mathrm{mg}$ & $3.00 \mathrm{mg}$ & mean & $\mathbf{0 . 0 0}$ & $1.00 \mathrm{mg}$ & $2.00 \mathrm{mg}$ & $3.00 \mathrm{mg}$ & mean \\
\hline \multicolumn{16}{|c|}{ First season } \\
\hline $25 \%$ F.C. water & 10.54 & 12.50 & 16.89 & 13.63 & 13.37 & 4.62 & 6.44 & 8.71 & 9.27 & 7.26 & 7.26 & 9.82 & 9.05 & 11.06 & 9.30 \\
\hline $50 \%$ F.C.water & 12.35 & 17.29 & 20.23 & 14.43 & 16.12 & 9.30 & 10.88 & 10.21 & 8.27 & 9.66 & 7.03 & 11.22 & 13.59 & 11.59 & 10.85 \\
\hline 75\% F.C.water & 10.82 & 15.34 & 17.22 & 15.96 & 14.84 & 6.75 & 9.34 & 7.23 & 6.33 & 7.41 & 7.45 & 12.61 & 11.66 & 10.92 & 10.66 \\
\hline 100\%F.C.water & 9.08 & 11.83 & 10.31 & 10.54 & 10.44 & 4.30 & 4.53 & 4.46 & 4.86 & 4.52 & 5.43 & 7.44 & 7.48 & 7.01 & 6.84 \\
\hline Mean & 10.68 & 14.24 & 16.16 & 13.64 & & 6.24 & 7.79 & 7.65 & 7.17 & & 6.79 & 10.27 & 10.44 & 10.14 & \\
\hline \multicolumn{3}{|c|}{ L.S.D.0.05 between water levels } & & 0.78 & & \multicolumn{5}{|c|}{0.94} & \multicolumn{5}{|c|}{0.95} \\
\hline \multicolumn{3}{|c|}{ L.S.D. 0.05 between Algae conc. } & & 0.78 & & \multicolumn{5}{|c|}{0.94} & \multicolumn{5}{|c|}{0.95} \\
\hline \multicolumn{3}{|c|}{ L.S.D.0.05 F.C. levels*Algae conc. } & & 1.57 & & & & 1.90 & & & & & 1.91 & & \\
\hline \multicolumn{16}{|c|}{ Second season } \\
\hline $25 \%$ F.C.water & 11.69 & 15.20 & 16.19 & 16.69 & 14.94 & 5.38 & 5.38 & 7.01 & 7.75 & 6.72 & 6.94 & 10.23 & 12.13 & 8.63 & 9.48 \\
\hline 50\%F.C.water & 13.12 & 16.31 & 19.31 & 14.88 & 16.08 & 7.53 & 8.23 & 10.42 & 9.09 & 8.81 & 7.36 & 11.78 & 15.30 & 11.56 & 11.50 \\
\hline 75\%F.C.water & 11.93 & 18.52 & 18.52 & 15.02 & 16.05 & 7.02 & 8.54 & 8.68 & 8.04 & 8.07 & 8.79 & 12.50 & 13.10 & 11.84 & 11.55 \\
\hline 100\%F.C.water & 11.34 & 14.13 & 13.01 & 12.36 & 12.69 & 4.28 & 4.88 & 5.79 & 5.82 & 5.19 & 6.76 & 7.50 & 7.68 & 7.60 & 7.38 \\
\hline Mean & 12.00 & 16.26 & 16.76 & 14.74 & & 6.05 & 7.10 & 7.97 & 7.67 & & 7.46 & 10.50 & 12.05 & 9.90 & \\
\hline \multicolumn{3}{|c|}{ L.S.D.0.05 between water levels } & & 1.34 & & \multicolumn{4}{|c|}{1.14} & & \multicolumn{5}{|c|}{0.68} \\
\hline \multicolumn{3}{|c|}{ L.S.D.0.05 between Algae conc. } & & 1.34 & & \multicolumn{4}{|c|}{1.14} & & \multicolumn{5}{|c|}{0.68} \\
\hline \multicolumn{3}{|c|}{ L.S.D.0.05 F.C. levels*Algae conc. } & & 2.68 & & \multicolumn{4}{|c|}{2.28} & & \multicolumn{5}{|c|}{1.37} \\
\hline
\end{tabular}


In this regard, Mutale-Joan et al. (2020) reported the concentration of an algal biostimulant appears to be a critical factor for its effectiveness. Also, FilippoHerrera et al.(2021) reported that application of SLEs at low concentrations stimulated shootlength, rootlength of Mungbean and dry weight responded to the SLEs concentration.

\section{Chemical analysis:}

Data in Table (7) showed that the highest chlorophyll a and chlorophyll b content were obtained after foliar spray with $3.0 \mathrm{mg} / \mathrm{l}$ algae (81.74mg/100gf.w.) in the first season and (73.66mg/100g f.w.) in the second season. As for the interaction between levels of water FC and algal conc.(up to $25 \%$ ) +2 or $3 \mathrm{mg} / \mathrm{l}$ gave the highest values of both seasons. Concerning chlorophyll $b$ foliar application with 3 and $2 \mathrm{mg} / \mathrm{l}$ produced the highest chlorophyll B contents (29.99, and $26.88 \mathrm{mg} / 100 \mathrm{~g}$ f.w.) in the first season and second season, respectively. Among substances with hormone-like activity, exogenously applied polyamines can be covalently conjugated to chlorophyll-bound proteins by Algae extracts, thus improving chlorophyll stability during leaf senescence (Lin and Lin, 2019). It is generally known that photosynthetic efficiency depends on photosynthetic pigments such as chlorophyll "a" and chlorophyll "b" which play an important role in photochemical reactions of photosynthesis (Taiz and Zeiger, 2002). Drought stress has capacity to inhibit the photosynthesis of plants by affecting cholorophyll components, causing changes in chlorophyll content, and damaging the photosynthetic apparatus in plants (Iturbe Ormaetxe et al., 1998).

For total carbohydrate content, the highest significant increase was obtained by foliar spray by 2 and $3 \mathrm{mg} / \mathrm{l}$ algae of $12.94 \%$ and $12.21 \%$ compared with the control in the first and second seasons respectively, and it was $14.58 \%$ when used $2 \mathrm{mg} / \mathrm{l}$ algae $+75 \% \mathrm{FC}$ in the first season. These results are in harmony with obtained by Farouk et al.,(2011)on radish. Also, there was an increase in perecentage of carbohydrate which may be due to the increase of photosynthesis pigments (chlorophyll a, chlororll $\mathrm{b}$ content and total carotene). For Anthocyanin content, there was a significant difference between treatments and also the $2 \mathrm{mg} / \mathrm{l}$ with $75 \%$ FC gave the highest significant increases compared with the control.

It is clear from data in Table (8) that there were significant effects due to the interaction between the application of algae and different irrigation levels on the carotene and proline content compared to zero algae treatment. The highest carotene content ( 23.32 and $21.87 \mathrm{mg} / 100 \mathrm{~g}$ leaves fresh weight was found using algae at $2 \mathrm{mg} / \mathrm{l}$ combined with $100 \%$ FC which was statistically similar to spray of $3 \mathrm{mg} / \mathrm{l}$ algae combined with $25 \& 50 \%$ FC specify in the second seasons, the lowest significant amount of proline was found with the application of algae extract at $3 \mathrm{mg} / 1$ with $100 \%$ FC. In general all treatments of algae alone or combined with irrigation levels led to the lowest significant amounts of carotene and proline compared the irrigation treatments alone. (zero algae treatment).

These results may due to effect of cytokinin in algae extracts (as activators) increasing carbohydrates and protein synthesis and causes transport of many solutes from older parts to the new ones (Salisbury and Ross, 1974). In this connection, Leopold and Kawase (1964) mentioned that cytokinins stimulate the movement of sugars, starch, amino acids, and many other solutes from mature organs to primary tissues of other ones. Also, Phyto-hormones such as cytokinins, betaines, and gibberellins in extracts may play a role in reducing chlorophyll degradation mainly through inhibition of chlorophyllase activity (Martinez et al., 1996).

The role of natural activators may be attributed to increasing the promoters in the plant tissues at the expense of the inhibitors to induce growth, as reported by Kenneth (1979) who found that plant growth not depended on a single hormonal type such as auxin, but is shared by several hormones especially auxins, cytokinins, gibberellins and ethylene. This further is subjected to modification by certain naturally occurring inhibitors, namely phenols, flavonols, and abscisic acid. Which have been known to modify the activity of IAA-oxidase and might therefore be acting on growth and production by way of changes in endogenous auxin levels. In addition, cytokinin can prevent the emanation of some positive inhibitory influences from the leaves under non - inductive conditions (Audus, 1972). Many abiotic factors (drought, salinity, extreme temperatures) are manifested in plants as osmotic stresses, leading to the accumulation of reactive oxygen species (ROS) that damage DNA, lipids, carbohydrates, and proteins and also cause aberrant cell signaling (Panda et al., 2012).

In conclusion algae extract can be used as a foliar spray on plants at different concentrations. These treatments decreases the water use at least by $25 \%$ and increases most plant growth parameters. Seaweeds extract application have proven their effectiveness in plants. Small amounts of seaweed extract expended on the treatment of plants may lead to great beneficial outcomes, not only in regard to optimal growth conditions, but also under different biotic and abiotic stress conditions.

Due to the diversity of active compounds present in seaweed cells, the growth and development of cultivated plants can be affected by two ways. 
Table 7: Means of chlorophyll a, and chlorophyll b (mg/100g fresh weight) and Anthocyanin contnt of Acokanthera oblongifolia Hochst. as influenced by different irrigation levels(F.C.), foliar spray of different concentrations of sea- algae extract and interaction between them during the two successive seasons of 2019 and 2020.

\begin{tabular}{|c|c|c|c|c|c|c|c|c|c|c|c|c|c|c|c|}
\hline \multirow{2}{*}{$\begin{array}{l}\text { Algae extract } \\
\text { Water level }\end{array}$} & \multicolumn{4}{|c|}{ Chlorophyll a (mg/100gf.w.) } & \multicolumn{6}{|c|}{ Chlorophyll b (mg/100gf.w.) } & \multicolumn{4}{|c|}{ Anthocyanin content } & \multirow[b]{2}{*}{ mean } \\
\hline & 0.00 & 1.00 & 2.00 & $3.00 \mathrm{mg} / \mathrm{l}$ & Mean & $0.00 \mathrm{mg} / \mathrm{l}$ & $1.00 \mathrm{mg} / \mathrm{l}$ & $2.00 \mathrm{mg} / \mathrm{l}$ & $3.00 \mathrm{mg} / \mathrm{l}$ & mean & 0.00 & 1.00 & 2.00 & $3.00 \mathrm{mg} / \mathrm{l}$ & \\
\hline \multicolumn{16}{|c|}{ First season } \\
\hline 25\%F.C.water & 60.46 & 67.16 & 65.45 & 62.71 & 63.94 & 20.61 & 23.99 & 24.51 & 25.14 & 23.56 & 2.49 & 2.69 & 2.85 & 268 & 2.68 \\
\hline 50\%F.C.water & 61.46 & 81.39 & 82.99 & 89.58 & 78.85 & 25.46 & 24.99 & 24.90 & 29.82 & 26.29 & 2.17 & 3.36 & 2.87 & 3.44 & 2.96 \\
\hline 75\%F.C.water & 57.67 & 80.92 & 84.50 & 88.49 & 77.89 & 26.90 & 32.31 & 34.38 & 31.56 & 31.29 & 2.18 & 3.16 & 6.29 & 5.94 & 4.55 \\
\hline 100\%F.C.water & 58.20 & 86.47 & 87.30 & 86.18 & 79.53 & 28.19 & 30.53 & 32.71 & 33.45 & 31.22 & 2.94 & 3.15 & 3.38 & 3.15 & 3.15 \\
\hline Mean & 59.45 & 78.98 & 80.06 & 81.74 & & 25.29 & 27.95 & 29.12 & 29.99 & & 2.60 & 3.09 & 3.85 & 3.80 & \\
\hline \multicolumn{4}{|c|}{ L.S.D.0.05 between water levels } & 5.88 & & & & 1.14 & & & & & 0.27 & & \\
\hline \multicolumn{4}{|c|}{ L.S.D. 0.05 between Algae conc. } & 5.88 & & & & 1.14 & & & & & 0.27 & & \\
\hline \multicolumn{4}{|c|}{ L.S.D.0.05 F.C. levels*Algae conc. } & 11.76 & & & & 2.29 & & & & & 0.55 & & \\
\hline \multicolumn{16}{|c|}{ Second season } \\
\hline $25 \%$ F.C.water & 45.67 & 53.56 & 57.76 & 55.29 & 53.07 & 15.62 & 18.62 & 18.54 & 18.45 & 17.81 & 3.36 & 3.68 & 4.01 & 3.11 & 3.54 \\
\hline $50 \%$ F.C.water & 63.51 & 67.06 & 62.56 & 62.38 & 63.88 & 21.56 & 24.95 & 25.20 & 26.39 & 24.52 & 2.83 & 4.08 & 4.57 & 3.87 & 3.84 \\
\hline 75\%F.C.water & 58.41 & 76.99 & 80.32 & 85.84 & 75.39 & 24.27 & 27.06 & 27.60 & 27.37 & 26.57 & 3.48 & 3.83 & 6.96 & 7.35 & 5.40 \\
\hline 100\%F.C.water & 77.33 & 77.34 & 82.17 & 91.16 & 82.00 & 29.49 & 36.08 & 36.09 & 34.07 & 33.93 & 3.94 & 4.49 & 4.14 & 4.05 & 4.16 \\
\hline Mean & 61.23 & 68.73 & 70.70 & 73.66 & & 22.73 & 26.68 & 26.86 & 26.57 & & 3.40 & 4.02 & 4.92 & 4.59 & \\
\hline \multicolumn{4}{|c|}{ L.S.D.0.05 between water levels } & 4.07 & & & & 0.25 & & & & & 0.44 & & \\
\hline \multicolumn{4}{|c|}{ L.S.D.0.05 between Algae conc. } & 4.07 & & & & 0.25 & & & & & 0.44 & & \\
\hline \multicolumn{4}{|c|}{ L.S.D.0.05 F.C. levels*Algae conc. } & 8.14 & & & & 0.50 & & & & & 0.87 & & \\
\hline
\end{tabular}


Table 8: Means of proline content (mg/100g), total carbohydrate(\%) and carotene content(mg/100g leaves fresh weight) of Acokanthera oblongifolia Hochst. as influenced by different irrigation levels(F.C.), foliar spray of different concentrations of sea- algae extract and interaction between them during the two successive seasons of 2019 and 2020.

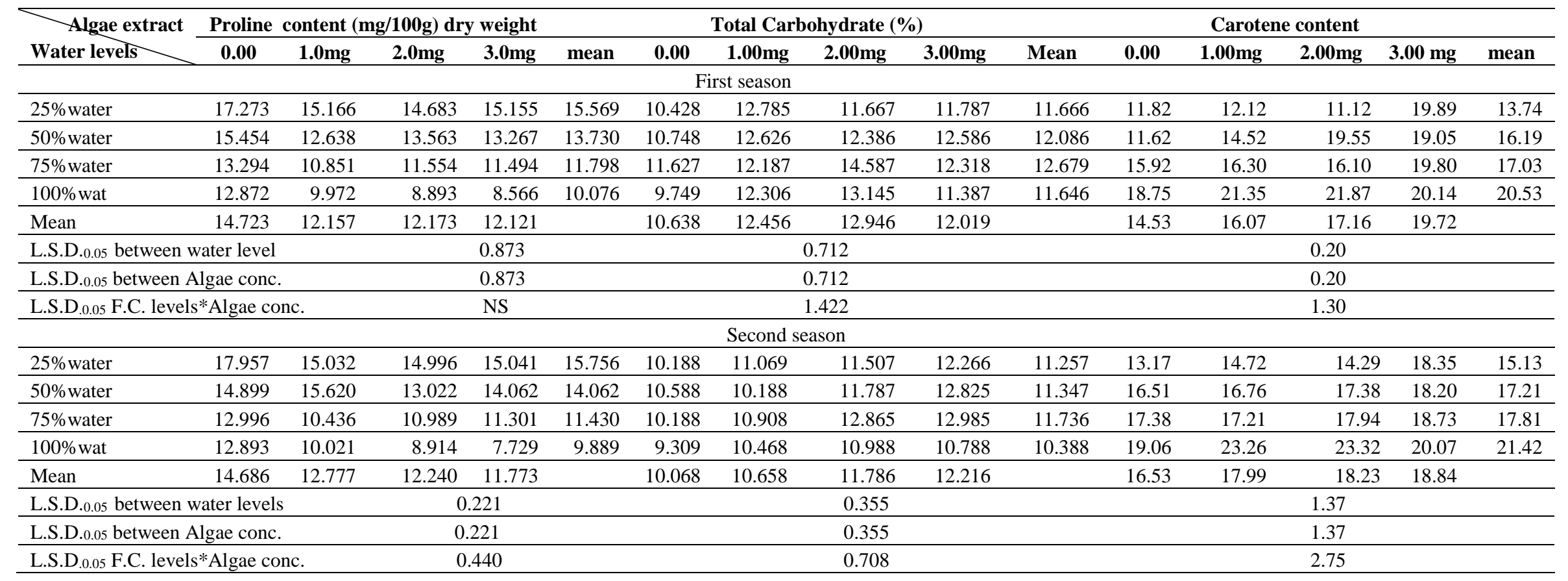


Seaweeds extract or products containing such ingredients have a positive impact on crop plants, not only because of the direct stimulation of their growth and metabolisms, e.g. nutrient uptake, but also indirectly, through improvement of the soil condition (hydration, structure) or enhancement of the number of soil microorganisms resulting from the creation of favorable conditions for their development. Products containing algal extracts not only stimulate the growth and development of crops, thus increasing the yield, but also improve their quality and nutritional values (Battacharyya et al. 2015).

\section{REFERENCES}

Albrecht, L. P. (2011). Manejo de biorregulador nos componentes de produção e desempenho das plantas de soja. Bioscience Journal, 27: 865876, 2011.

Albrecht, L. P. (2012). Biorregulador na composição química e na produtividade de grãos de soja. Revista Ciência Agronômica, 43: 774-782.

Ali, H.M.H.; N. A.M. EL-Said; S.M.M. Salem (2014). Physiological effects of diatomaceous earth on Meentha viridis plants grown under drought conditions. Sci. J. Flowers and Ornamental Plants, 1(2): 101-115.

Arnold, T.H. and B.C. De Wet (1993). Plants of southern Africa: names and distribution. Memoirs of the Botanical Survey of South Africa No. 62. National Botanical Institute, Pretoria.

Asghari, M.T., J. Daneshian and H.A. Farahani (2009). Effects of drought stress and planting density on quantity and morphological characteristics of chicory (Cichorium intybus L.). Asian J. Agric. Sci., 1(1): 12-14.

Audus, L.J. (1972). Plant Growth Substances, Vol. 1: Chemistry and Physiology. Leonard Hill Books, 158 Buckingham Palace Road, London, $3^{\text {rd }}$ Ed., 533pp.

Bates, L.; R. Waldern and I. Teare (1973). Rapid determination of free proline for water stress studies. Plant and Soil, 39: 205-207.

Battacharyya D.; M. Z. Babgohari; P. Rathor; B. Prithiviraj (2015) Seaweed extracts as biostimulants in horticulture. Hortic. Sci.196: $39-48$

Bayona-Morcillo, P.J.; B.M.Plaza; C. GómezSerrano; E.Rojas; S. Jiménez-Becker (2020). Effect of the foliar application of cyanobacterial hydrolysate (Arthrospira platensis) on the growth of Petunia $\mathrm{x}$ hybrida under salinity conditions. Environ. Biol. Fishes, 32: 40034011.2020
Collier, M.D.; M.N. Fotelli; S. Kopriva; H. Rennenberg; D.E. Hanke; A. Geßler (2003). Regulation of nitrogen uptake by Fagus sylvatica on a whole plant level-interactions between cytokinins and soluble $\mathrm{N}$ compounds. Plant Cell. Environ, 26: 1549-1560.

Dhanda, S.S., G.S. Sethi and R.K. Behl (2004). Indices of drought tolerance in wheat genotypes at early stages of plant growth. J. Agron. Crop Sci., 190: 1-6.

EI-Juhany, I. and M.I. Aref (2005). Growth and dry matter partitioning of Lenceana leucocephala trees as affected by water stress. Alexandria J. Agric. Res., 44(2): 237-259.

EL-Sayed, B. A.; T. M. Noor EL Deen; M. A. Ahmed and S. M. Shahin (2015). Effect of some natural activators on growth and quality of seashore paspalum truf. Sci. J. Ornamental Plants, 2 (1):149-156.

Farouk, S.; A.A. Mosa; A.A. Taha; M. I. Heba and A.M. EL-Gahmery (2011). Protective effect of humic acid and chitosan on radish (Raphanus sativus L. var. sativus) plants subjected to cadmium stress. J. of Stress Physiol. and Biochem., 7(2): 99-116.

Filippo- Herrera, D. A.; R. M. Hemamdez; H. Ocampo- Alvarez; C.V. Sanchez-Hernandez; M. Munoz -Ochoaz and G. Hernandez (2012). Seaweed liquid extracts induce hormeitc growth responses in mung bean (Vigna radiata) plants. J. Appl. Phycol. April.

Gomez, K. and A. A.Gomez (1984). Statistical Procedues for Agricultural Research. $2^{\text {nd }} \mathrm{ed}$. An Int. Rice Res. Insti. Book. John Wiley Sons, New York, USA.

Gorka B.; K. Korzeniowska; J. Lipok and P. Pwieczork (2018). The Biomass of Algae and Algal Extracts in Agricultural production. Speringer chan In Book:Algae Biomass: Characterstics and Applications, PP.103-114.

Hamayun, M., E.Y. Sohn, S.A. Khan, Z.K. Shinwari, A.L. Khan and I. J. Lee (2010). Silicon alleviates the adverse effects of salinity and drought stress on growth and endogenous plant growth hormones of soybean (Glycine max L.). Pak. J. Bot., 42(3): 1713-1722.

Handreck, k. and N. Black (2002). Growing Media for Ornamental Plants and Turf, $3^{\text {rd }}$ Ed., Univ. of New South Wales Press Ltd., Sydney, Australia, 542pp.

Hedge, J.E. and B. T. Hofreiter (1962). In: Carbohydrate Chemistry, $17^{\text {th }} \mathrm{Ed}$. (Whistler R. L. and Be Miller, J.N.), Academic Press, New York.

Iturbe Ormaetxe, I., P.R. Escuredo, C. Arrese-Igor and M. Becana (1998). Oxidative damage in pea plants exposed to water deficit or paraquat. Plant Physiol., 116: 173-181. 
Jackson, N. L. 1958. Soil Chemical Analysis Constable. Ltd Co., London, 498 p.

Jones, H.G. (1992). Plants and Microclimate; A Quantitative Approach to Environmental Physiology. 2nd Ed. Cambridge Univ. Press, Cambridge, UK.

Karamanos, A.S. (1980). Water stress and leaf growth of field beans (Vicia faba) in the field: Leaf number and total area. Ann. Bot. 42: 13931402.

Kavalco, S. A. F. 2014. Desenvolvimento da soja com aplicações de hormônios em diferentes densidades de cultivo. Revista Brasileira de Agropecuária Sustentável, 4: 112-116.

Kenneth, V.T. (1979). Physiology of Plant Growth and Development. B.Willkins TaTa, McGrawHill Publishing Co. Ltd., New Delhi.

Kidokoro, S., K. Maruyama, K. Nakashima, Y. Imura, Y. Narusaka, Z.K. Shinwari, Y. Osakabe, Y. Fujita, J. Mizoi, K. Shinozaki and K. Yamaguchi-Shinozaki (2009). The phytochrome-interacting factor PIF7 negatively regulates DREB1 expression under circadian control in Arabidopsis. Plant Physiology, 151(4): 2046-2057.

Kozlowski. T.L. (1982). Water supply and tree growth, Part I. Water deficits. For. Abstr., 43: 57- 95.

Leopold, A.C. and M. Kawase (1964). Senescence of a trifoliate bean leaf caused by treating the primary leaves of cutting with BA. Amer. J. Bot., 51: 294-298.

Lin, H.Y. and H. J. Lin (2019). Polyamines in Microalgae: Something Borrowed, Something New. Mar. Drugs ,17,1

Mancinelli, A.L.; A. M. Hoff and M. Cottrell (1988). Anthocyanin production in Chl-rich and Chl-poor seedlings. Plant Physiol., 86: 652-654

Maqsood, M. and S.N.A. Ali (2007). Effects of drought on growth, development, radiation use efficiency and yield of finger millet (Eleucine coracana). Pak. J. Bot., 39(1): 123-134.

Martinez, G.A.; A.R.Chaves and M.C. Añon (1996). Effect of exogenous application of gibberellic acid on color change and phenylalanine ammonia-lyase, chlorophyllase, and peroxidase activities during ripening of strawberry fruit (Fragaria x ananassa Duch.). J. Plant Growth Regul., 15: 139-146.

Meyer, F.R.; V.O. Junior; J.V. Silva Bernardes and V.P. DE Mirandna Coelho (2021). Foliar spraying of a seaweed-based biostimulant in soybean Caatinga, Mossoro, v. 34, n1, p 99107, Jan-Mar.

Moran R. (1982). Formula determination of chlorophyll pigment extracted with N,N diethyl formamide. Plant physiol., 69:1376-1381.
Mutale-Joan, C.; B. Redouane; E. Najib; K.Yassine; K. Lyamlouli; S.Laila; Y. Zeroual andH. El Arroussi (2020). Screening of microalgae liquid extracts for their biostimulant properties on plant growth, nutrient uptake and metabolite profile of Solanum lycopersicum L. Sci. Rep., 10, 2820.

Panda, D.; K. Pramanik and B.R.Nayak (2012).Use of seaweed extracts as plant growth regulators for sustainable agriculture. Int. J.Bio-resource Stress Manag., 3: 404-411.

Parsons, L.R. (1982). Plant responses to water stress. In: Breeding plants for less favorable environments. (Eds.): M.N. Christiansen and C.F. Lewis, pp. 175-192.

Pooley. E (1993). The complete field guide to Trees of Natal, Zululand \& Transkei. Natal Flora Publications Trust: Durban, South Africa.

Poschenrieder C.; C. Cabot; S. Martos ;B. Gallego and J.Barceló. 2013. Do toxic ions induce hormesis in plants? Plant Sci., 212: 15-25.

Ramya S. S.; N. Vijayanand and S. Rathinavel (2015). Foliar application of liquid biofertilizer of brown alga Stoechospermum marginatum on growth, biochemical and yield of Solanum melongena. Int. J. Recycl Org. Waste Agric., 4:167-173.

Safaei, Z.; M. Azizi; Y. Maryam; H. Aroieea and G. Davarynejed (2014). The effect of different irrigation intervals and anti- transpiration compounds on yield and yield components of Black Cumin (Nigella sativa) Int. J. Adv. Biol. Biom. Res.,2(4):326-335.

Salisbury, F.B. and C.W. Ross. (1974). Plant Physiology, Wordsworth Publishing Inc., Belmont, California, $2^{\text {nd }}$ Ed., 422pp.

Shahid, M.; N. K. Niazi; J. Rinklebe; J. Bundschuh; C. Dumat and E.Pinelli (2020). Trace elementsinduced phytohormesis: a critical reviewand mechanistic interpretation. Crit. Rev. Environ. Sci. Technol., 50:1984-2015

Shakirova, F.M.; A. R. Sakhabutdinova; M. V. Bezrukova; R.A. Fatkhutdinova and D.R. Fatkhutdinova (2003). Changes in the hormonal status of wheat seedlings induced by salicylic acid and salinity. Plant Sci., 164: 317-322.

Stamatiadis S.;L. Evangelou ; J.C.Yvin; C. Tsadilas; J.M.G. Mina and F. Cruz (2014). Responses of winter wheat to Ascophyllum nodosum (L.) Le Jol. extract application under the effect of $\mathrm{N}$ fertilization and water supply. J. Appl. Phycol., 27: 589-600.

Stirk, W. A. (2004). Changes in cytokinin and auxin concentrations in seaweed concentrates when stored at an elevated temperature. J. Appl. Phycology, 16: 31-39.

Taiz, L. and E. Zeiger (2002). Plant Physiology, 3rd Edition. Senauer Assoc., Sunderland. MA. 690 pps. 
Taiz, L. (2017). Fisiologia e desenvolvimento vegetal. 6. ed. Porto Alegre, RS: Artmed, 888 p.

Tarakhovskaya, E.R.; Y.I. Maslov and M.F.Shishova (2007). Phytohormones in Algae. Russ. J. Plant Physiol., 54: 163-170.

Wang, Y.; S. Mopper and K. H. Hasenstein (2001). Effects of Salinity on Endogenous Aba, Iaa, Ja, and $\mathrm{Sa}$ in Iris hexagona. J. Chem. Ecol., 27: 327-342.
Warrag, M.O.A. and A.E. Hall (1984). Reproductive responses of cowpea (Vigna unguiculata L. Walp) to heat stress. II. Responses to night air temperature. Field Crops Res., 8: 17-33.

Wellburn, A. R.(1994). The spectral determination of chlorophylls a and $\mathrm{b}$, as well as total carotenoids, using various solvents with spectrophotometers of different resolution. J. Plant Physiol., 144(3): 307-313.

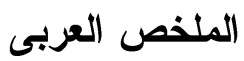

\section{استجابه نباتات الاكوكاتثير المستخلص الأعشاب البحرية في المراحل الاولى للنمو تحت الإجهاد}

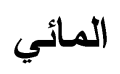

\section{هاى اسماعيل محمد الجداوى، منى بلر الاين الايب}

فرع بحوث نباتات الزينة بأنطونياد - الأسكندرية - قسم بحوث الزينة وتتسيق الحدائق - معهد بحوث البساتين - مركز البحوث الزراعية لائ

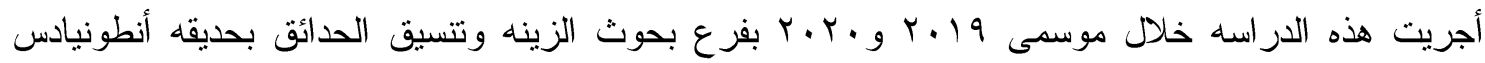

التابعه لمعهد بحوث البساتين - مركز البحوث الزراعيه مصر وذلك لدراسه تأثير الرش بمستخلصات الطحالب

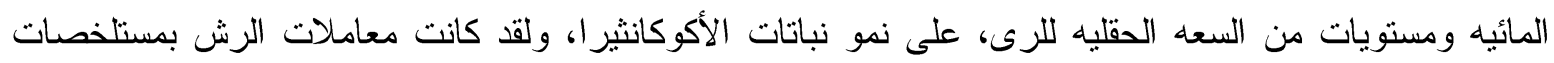

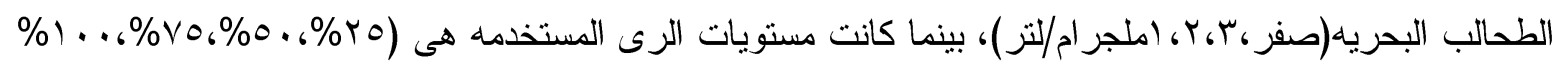

سعه حقليه).

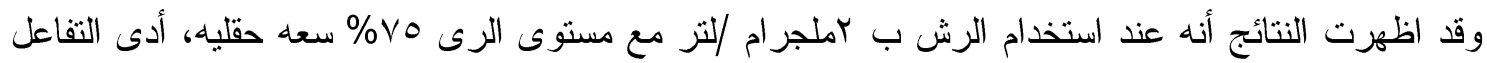
بينهم الى وجود زياده معنويه بطول النباتات وعدد الاور اق و الفروع لكل نبات وكذللك الوزن الطاز جرت للنباتات. إيضا أظهرت النتائج تحسن و اضح وزياده معنويه فى صفات المجمو ع الجذرى من حيث حجم الجذور و الوزن

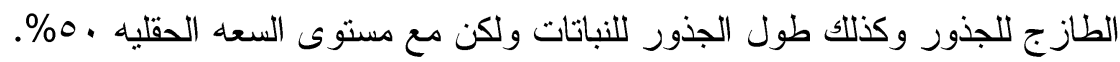

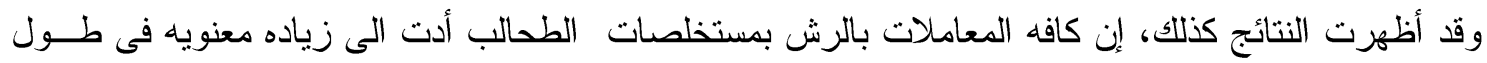

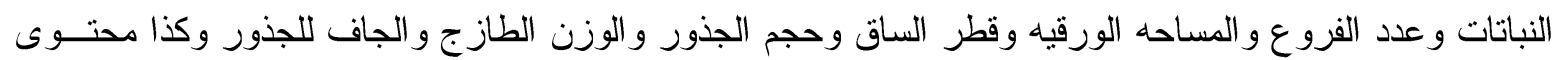

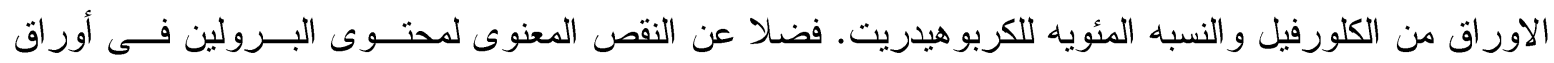
النبات.

وفقا لهذه النتائج، يمكن إستتاج أن زر اعه نباتات الاكوكانثير ا والتى يبلغ عمرها 7 أنشهروريها بأربع مستويات

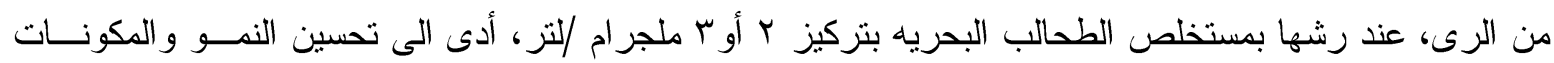
الكيميائيه للنباتات تحت مستوى الإجهاد المائى. 